\title{
Pengaruh Pengungkapan Corporate Social Responsibility terhadap Kinerja Keuangan Perusahaan selama Pandemi Covid-19
}

\author{
Nabila Hermawan Putri*, Yuni Rosdiana \\ Bandung, Indonesia. \\ *nabilahrmwnptr@gmail.com, yunisjafar95@gmail.com
}

Prodi Akuntansi, Fakultas Ekonomi dan Bisnis, Universitas Islam

\begin{abstract}
The existence of the Covid-19 pandemic has a direct impact on the decrease in the income of the Indonesian people, especially the middle class economy. This makes the company must be aware to the community by implementing CSR.CSR disclosure helps companies to inform the CSR impelementation so that the company can get a good image in the eyes of stakeholders. This good image is expected to have a positive impact on the financial performance. This study aims to determine the CSR Disclosure, financial performance, and the effect of CSR Disclosure on financial performance (proxied by ROA) in financial sector companies listed on the IDX during the Covid-19 pandemic.The research method used in this research is verification methods with a quantitative approach. Sources of data in this study is secondary data obtained from website IDX.Hypothesis testing in this study uses simple regression analysis consisting of T Test, and Coefficient of Determination. The test results show that all companies have disclosed CSR in the economic category, but not all have implemented social and environmental categories, financial performance is still below industry standards, and the CSR Disclosure has no effect on Financial Performance (proxied by ROA) during the Covid-19 Pandemic.
\end{abstract}

Keywords: Covid-19, Financial Performance, Corporate Social Responsibility Disclosure, Return on Asset.

\begin{abstract}
Abstrak. Adanya pandemi Covid-19 memberikan dampak langsung terhadap penurunan pendapatan masyarakat Indonesia, khususnya pada masyarakat ekonomi kelas menengah. Hal ini yang menjadikan perusahaan harus peka terhadap masyarakat dengan menerapkan Corporate Social Responsibility (CSR). Pengungkapan CSR membantu perusahaan untuk menginformasikan berbagai kegiatan penerapan CSR yang dilakukan perusahaan agar perusahaan dapat mendapatkan citra baik di mata stakeholder. Citra baik ini diharapkan akan berdampak positif pada kinerja keuangan perusahaan. Penelitian ini bertujuan untuk mengetahui pengungkapan Corporate Social Responsibility (CSR), kinerja keuangan dan pengaruh pengungkapan Corporate Social Responsibility (CSR) terhadap kinerja keuangan (diproksikan dengan ROA) pada perusahaan sektor keuangan yang terdaftar di BEI selama pandemi Covid-19. Metode penelitian yang digunakan dalam penelitian ini yaitu metode verifikatif dengan pendekatan kuantitatif. Sumber data yang digunakan dalam penelitian ini adalah data sekunder yang diperoleh dari situs resmi BEI. Pengujian hipotesis dalam penelitian ini menggunakan analisis regresi sederhana yang terdiri dari Uji T, dan Koefisien Determinasi. Hasil pengujian menunjukkan bahwa seluruh perusahaan telah melakukan pengungkapan CSR pada kategori ekonomi, namun tidak seluruhnya menerapkan kategori sosial dan kategori lingkungan, kinerja keuangan masih berada di bawah standar industri, dan Pengungkapan Corporate Social Responsibility (CSR) tidak berpengaruh terhadap Kinerja Keuangan (diproksikan dengan ROA) selama Pandemi Covid-19.
\end{abstract}

Kata Kunci: Covid-19, Kinerja Keuangan, Pengungkapan Corporate Social Responsibility, Return on Asset. 


\section{A. Pendahuluan}

Alasan utama didirikannya suatu perusahaan yaitu untuk meningkatkan profit atau laba (1). Laba digunakan sebagai suatu pengukuran untuk kinerja keuangan perusahaan (2). Kinerja keuangan biasanya digunakan untuk mengukur pencapaian yang telah diperoleh dalam periode tertentu oleh setiap perusahaan (3). Kinerja keuangan penting untuk diukur sebagai sarana perbaikan operasional yang akan dipergunakan sebagai bahan evaluasi agar perusahaan mengalami pertumbuhan keuangan yang lebih baik (4).

Turun naiknya kinerja keuangan dapat disebabkan oleh faktor yang dapat diprediksi seperti turunnya penjualan dan pelambatan pertumbuhan kredit atau faktor yang tidak dapat diprediksi seperti munculnya pandemi akibat Covid-19. Munculnya Covid-19 ini cukup mengguncang kinerja keuangan perusahaan. Kinerja keuangan beberapa perusahaan di masa pandemi banyak terjadi penyusutan yang cukup signifikan. Penurunan pendapatan perusahaan ini disebabkan karena adanya kebijakan PSBB (Pembatasan Sosial Berskala Besar) yang dikeluarkan pemerintah untuk mengurangi kegiatan masyarakat yang berimbas pada penutupan beberapa sektor usaha. Menurut Samsul Hidayat selaku Direktur Eksekutif Asosiasi Emiten Indonesia (2020) bahwa pemberhentian kegiatan operasional beberapa sektor usaha akibat dari PSBB menyebabkan penurunan pendapatan yang cukup signifikan di beberapa emiten. Salah satunya terjadi pada sektor keuangan, yaitu pada perusahaan perbankan. Perusahaan BUMN seperti Bank BRI dan Bank Mandiri keduanya mengalami penurunan laba bersih sebesar 45,78\% dan 37,71\% pada tahun 2020 dibandingkan sebelum pandemi pada tahun 2019.

Selain berdampak pada perusahaan, adanya pandemi ini cukup berdampak signifikan pada masyarakat khususnya masyarakat ekonomi kelas menengah. Kepala Badan Pusat Statistik (BPS) Suhariyanto mengutarakan bahwa masyarakat yang memiliki penerimaan rendah lebih terkena dampak pandemi Covid-19 dibanding yang lainnya. Tidak hanya penurunan pendapatan, bahkan banyak masyarakat yang hidup tanpa pekerjaan dan pemasukan di tengah pandemi yang disebabkan oleh Covid-19 (5). Lalu, menurut perusahaan riset pasar Ipsos, 84\% masyarakat Indonesia mengalami penurunan pemasukan dan 3 dari 10 orang mengalami penurunan pemasukan mencapai 50\% jika dibandingkan dengan sebelum pandemi (6).

Banyaknya masyarakat yang terdampak pandemi Covid-19, sudah seharusnya perusahaan peka menghadapi situasi seperti ini, salah satunya melalui program CSR yang ada di masing-masing perusahaan (7). CSR merupakan sebuah teori mengenai perusahaan yang dihadapkan pada tanggung jawab terhadap masalah sosial dan lingkungan, tidak hanya masalah ekonomi saja (8). CSR merupakan suatu kewajiban yang harus dilakukan oleh perusahaan dan diatur dalam UU Nomor 40 Tahun 2007 dan PP Nomor 47 Tahun 2012.

Adanya kewajiban untuk melaksanakan program CSR dapat menjadikan banyak dorongan bagi perusahaan untuk mengungkapkan kegiatan CSR. Informasi yang terkandung dalam pengungkapan CSR yaitu mengenai kegiatan CSR yang diterapkan oleh perusahaan dan pengaruhnya terhadap sosial dan lingkungan. Informasi tersebut akan selaras dengan kepentingan stakeholders dan akan mempengaruhi perusahaan secara signifikan (9). Hal ini akan berguna bagi perusahaan untuk membangun dan meningkatkan legitimasinya dengan berbagai pelaku kepentingan (8).

Penerapan Corporate Social Responsibility memiliki manfaat yang banyak bagi masyarakat maupun perusahaan itu sendiri. Pelaksanaan CSR yang dilakukan oleh perusahaan dapat membantu masyarakat dari berbagai sektor seperti pada sektor pendidikan dengan mengadakan pendidikan yang layak bagi masyarakat sekitar. Lalu, benefit yang didapatkan perusahaan dari pelaksanaan CSR yaitu seperti menciptakan serta menjaga reputasi perusahaan, mengembangkan citra perusahaan di mata masyarakat, mengurangi risiko bisnis perusahaan, mempertahankan dan mengenalkan merk perusahaan, menjaga SDM yang dimiliki perusahaan agar tetap berkualitas, dan mendapatkan brand image perusahaan di mata masyarakat (10). Image yang baik di pandangan masyarakat inilah yang akan membangun reputasi perusahaan dimata masyarakat, dan menambah penawaran masyarakat terhadap produk perusahaan yang akan meningkatkan penjualan perusahaan seiring dengan peningkatan laba yang dapat mempengaruhi kinerja keuangan perusahaan (11). 

berikut:

Berlandaskan latar belakang tersebut, dirumuskan pertanyaan penelitian ini sebagai

1. Bagaimana pengungkapan corporate social responsibility pada Perusahaan Sektor Keuangan (Financials) yang Terdaftar di Bursa Efek Indonesia selama pandemic Covid19?

2. Bagaimana KinerjaKeuangan pada Perusahaan Sektor Keuangan (Financials) yang Terdaftar di Bursa Efek Indonesia setelah menerapkan corporate social responsibility selama pandemi Covid-19?

3. Apakah pengungkapan corporate social responsibility berpengaruh terhadap kinerja keuangan perusahaan(diproksikan dengan ROA) selama pandemi Covid-19? Adapun tujuan dari penelitian ini yaitu:

1. Untuk mengetahui pengungkapan Corporate Social Responsibility pada Perusahaan Sektor Keuangan (Financials) yang Terdaftar di Bursa Efek Indonesia selama pandemi Covid-19.

2. Untuk mengetahui kinerja keuangan pada Perusahaan Sektor Keuangan (Financials) yang Terdaftar di Bursa Efek Indonesia setelah menerapkan Corporate Social Responsibility selama pandemi Covid-19.

3. Untuk mengetahui pengaruh pengungkapan Corporate Social Responsibility terhadap kinerja keuangan perusahaan (diproksikan dengan ROA) selama pandemi Covid-19.

\section{B. Metodologi Penelitian}

Peneliti memakai metode penelitian verifikatif dengan pendekatan kuantitatif. Perusahaan sektor keuangan yang terdaftar di Bursa Efek Indonesia pada tahun 2020 yang berjumlah 105 perusahaan dijadikan sebagai populasi dalam penelitian ini. Lalu, purposivesampling digunakan sebagai teknik pengambilan sampel sehingga sampel penelitian sebanyak 60 perusahaan sektor keuangan.Sumber data yang digunakan merupakan data sekunder yang bersumberbdari laporan tahunan dan laporan berkelanjutan perusahaan sektor keuangan terdaftar di Bursa Efek Indonesia selama pandemi Covid-19.

\section{Pengungkapan Corporate Social Responsibility}

Konsep CSR pertama kali dikemukakan oleh Howard R. Bowen pada tahun 1953. Dalam konsep itu dijabarkan mengenai suatu kewajiban bagi perusahaan untuk menjalankan kebijakan dan keputusan yang sejalan dengan tujuan dan nilai-nilai yang dihendaki masyarakat (12). Konsep ini dikembangkan secara terus menerus oleh beberapa ahli dan peneliti lainnya, salah satunya oleh Visser, dkk. (2010) bahwa CSR mengacu pada kepercayaan umum yang dianut oleh sebagian besar masyarakat bahwasanya setiap bisnis modern memiliki tanggung jawab kepada masyarakat yang melampaui kewajiban mereka pada pemegang saham atau investor di setiap perusahaan. Pengukuran pengungkapan CSR menurut Standar Global Reporting Intitative G4 (14), yaitu:

1. Ekonomi

2. Lingkungan

3. Sosial

\section{Kinerja Keuangan}

Kinerjakeuangan merupakan paradigma yang mencerminkan suatu capaian yang dilakukan oleh perusahaan untu melihat bagaimana efisiensi dan efektivitasnya dalam memperoleh laba dan mengoperasikann suatu usahanya dalam suatu periode tertentu. Kinerjakeuangan diukur menggunakan dimensi profitabilitas dan indikator return on assets (ROA). ROA digunakan sebagai alat untuk mengukur besarnya efisien aset-aset yang digunakan perusahaan dengan menghitung kinerja atas total aset yang digunakan untuk menghasilkan keuntungan (15). Menurut Jewell, J.J. dan Mankin, J.A., ROA diukur menggunakan laba sebelum pajak dan total aset (16) 


\section{Hasil Penelitian dan Pembahasan}

\section{Uji Normalitas}

Tabel 1. Hasil Uji Normalitas

\begin{tabular}{|ll|r|r|}
\hline & & \multicolumn{1}{|c|}{ CSR } & \multicolumn{1}{|c|}{ KK } \\
\hline $\mathrm{N}$ & & 60 & 60 \\
Normal Parameters ${ }^{\mathrm{a}, \mathrm{b}}$ & Mean & .1380350 & .1213973 \\
& Std. Deviation & .08132328 & .05895448 \\
Most Extreme Differences & Absolute & .101 & .109 \\
& Positive & .101 & .109 \\
& Negative & -.098 & -.061 \\
Test Statistic & & .101 & .109 \\
Asymp. Sig. (2-tailed) & & $.200^{\mathrm{c}, \mathrm{d}}$ & $.073^{\mathrm{c}}$ \\
\hline
\end{tabular}

Sumber: Hasil Pengolahan Data dengan SPSS 23, 2021

Hasil tersebut menampakkan bahwa pada variabel CSR terlihat nilai signifikansi sebesar $0,200>0,050$. Lalu, untuk variabel kinerja keuangan diproksikan ROA memiliki nilai signifikansi sebesar 0,073> 0,050. Menurut Sofianty, D. dan Lestari, R. (2020), untuk menganalisis hasil uji normalitas data diketahui bila nilai Asymptotic Significance (2-tailed) dari tiap variabel $>0,05$, maka uji normalitas tersebut terpenuhi(17). Dilihat dari hasil di atas, data dari setiap variabel yang diuji dalam penelitian sudah berdistribusi normal.

\section{Analisis Regresi Linear}

Tabel 2. Analisis Regresi Linear Sederhana

\begin{tabular}{|c|c|c|c|c|c|}
\hline & \multicolumn{2}{|c|}{$\begin{array}{c}\text { Unstandardized } \\
\text { Coefficients }\end{array}$} & $\begin{array}{c}\text { Standardized } \\
\text { Coefficients }\end{array}$ & \multirow{2}{*}{$\mathrm{t}$} & \multirow{2}{*}{ Sig. } \\
\cline { 2 - 4 } & $\mathrm{B}$ & Std. Error & Beta & & \\
\hline (Constant) & .140 & .015 & & 9.338 & .000 \\
\hline CSR & -.133 & .094 & -.183 & -1.417 & .162 \\
\hline
\end{tabular}

Sumber: Data Penelitian yang Sudah Diolah, 2021

Berdasarkan tabel diatas, nilai konstanta $\alpha$ 0,140 dan nilai variabel CSR $-0,133$ atau dapat dijabarkan dalam persamaan regresi sebagai berikut:

$$
\text { Kinerja Keuangan = 0,140 }-0,133 \text { CSR }
$$

Dari persamaan linear sederhana di atas, dapat diinterpretasikan sebagai berikut:

1. Nilai konstanta 0,140 memiliki arti jika variabel CSR bernilai nol maka variabel KinerjaKeuangan akan memberikan nilai sebesar konstanta yaitu 0,140.

2. Nilai koefisien $-0,133$ memiliki arti jika variabel CSR meningkat satu satuan, maka variabel Kinerja Keuangan menurunsebesar 0,133. 


\section{Uji T}

Tabel 3. Uji T

\begin{tabular}{|c|c|c|c|c|c|}
\hline & \multicolumn{2}{|c|}{$\begin{array}{c}\text { Unstandardized } \\
\text { Coefficients }\end{array}$} & $\begin{array}{c}\text { Standardized } \\
\text { Coefficients }\end{array}$ & \multirow{2}{*}{$\mathrm{t}$} & \multirow{2}{*}{ Sig. } \\
\cline { 2 - 4 } & B & Std. Error & Beta & & \\
\hline (Constant) & .140 & .015 & & 9.338 & .000 \\
\hline CSR & -.133 & .094 & -.183 & -1.417 & .162 \\
\hline
\end{tabular}

Sumber: Data Penelitian yang Sudah Diolah, 2021

Tabel tersebut memperlihatkan nilai Sig. CSR sebesar 0,162 >0,05 yang berarti bahwa Haditolak dan Hoditerima, sehingga dapat diinterpretasikan bahwa tidak terdapat pengaruh yang signifikan antara Pengukuran Corporate Social Responsibility terhadap KinerjaKeuangan (diproksikan dengan ROA) selama Pandemi Covid-19.

\section{Koefisien Determinasi}

Tabel 4. Koefisien Determinasi

\begin{tabular}{|c|c|c|c|c|}
\hline Model & $\mathrm{R}$ & $\mathrm{R}$ Square & $\begin{array}{c}\text { Adjusted R } \\
\text { Square }\end{array}$ & $\begin{array}{c}\text { Std. Error of } \\
\text { the Estimate }\end{array}$ \\
\hline 1 & .183 & .033 & .017 & .0584575 \\
\hline
\end{tabular}

Sumber: Data Penelitian yang Sudah Diolah, 2021

Nilai R Square yang mewakili nilai koefisien determinasi menunjukkan angka 0,033. Hal ini menyiratkan besarnya Pengaruh Pengukuran Corporate Social Responsibility terhadap KinerjaKeuangan (diproksikan dengan ROA) selama Pandemi Covid-19 sebesar 3,3\% dan sisanya sebesar $96,7 \%$ dipengaruhi oleh variabel lain yang tidak diamati dalam penelitian ini.

\section{Pengungkapan Corporate Social Responsibility Perusahaan Sektor Keuangan yang} Terdaftar di Bursa Efek Indonesia selama Pandemi Covid-19

Dari 60 perusahaan sektorkeuangan yang diteliti dalam penelitian ini, nilai tertinggi pengungkapan CSR sebesar 0,3260 atau 32,60\% dari total keseluruhan item yang ada dalam standatar GRI G4. Rata-rata indeks CSR yang diungkapkan oleh perusahaan sektor keuangan sebesar 13,27\% item dari total keseluruhan item dalam standar GRIG4. Sementara itu, nilai terendah untuk indeks CSR yaitu sebesar 0,0256 atau 2,56\% item dari total keseluruhan item dalam standar GRIG4.

Jika dilihat berdasarkan kategori, seluruh perusahaan sektor keuangan telah mengungkapkan CSR pada kategori ekonomi dengan nilai tertinggi sebesar 0,59259 dan terendah sebesar 0,07407. Namun, masih terdapat beberapa perusahaan yang belum mengungkapkan CSR pada kategori lingkungan dan sosial. Terlihat pada hasil penelitian, nilai indeks terendah pada kategori lingkungan dan sosial sebesar 0 atau tidak mengungkapkan sama sekali.

Namun, jika dilihat dari keseluruhan perusahaan sektor keuangan yang terdaftar di Bursa Efek Indonesia pada tahun 2020 sejumlah 105 perusahaan, hanya 2 perusahaan yang tidak mengungkapkan CSR pada laporantahunan atau laporan berkelanjutannya. Hal ini jika dilihat secara keseluruhan dapat dinilai cukup baik, karena mayoritas perusahaan sektor keuangan tetap menerapkan CSR di masa pandemi COVID-19 ini. 
Kinerja Keuangan yang Diproksikan oleh Return on Assets (ROA) pada Perusahaan Sektor Keuangan yang Terdaftar di Bursa Efek Indonesia pada Tahun 2020

Adanya pandemi yang diakibatkan oleh Covid-19 ini cukup mencekik seluruh kalangan masyarakat tak terkecuali perusahaan sektor keuangan. Dilihat dari 105 perusahaan sektorkeuangan pada Bursa Efek Indonesia, 23 perusahaan diantaranya memiliki laba negatif atau kerugian di tahun 2020 ini. Selain itu, pada 60 perusahaan yang diamati dalam penelitian ini memiliki nilai rata-rata kinerja keuangan sebesar 0,0182 atau 1,82\%. Menurut Lukviarman N. (2006), standar rasio industri untuk ROA yaitu sebesar 5,98\% sehingga perusahaan dapat dikatakan sudah berkinerja baik jika memiliki nilai ROA di atas 5,98\% (18). Jika dilihat pada data hasil penelitian, perusahaan yang memiliki ROA di atas 5,98\% hanya Bank BTPN Syariah Tbk dan sisanya masih di bawah 5,98\%. Kecilnya ROA pada perusahaan sektor keuangan disebabkan oleh turunnya laba usaha selama pandemi Covid-19.

\section{Pengaruh Pengungkapan Corporate Social Responsibility terhadap Kinerja Keuangan Perusahaan selama Pandemi Covid-19}

Berdasarkan hasil pengujian mengenai pengaruh pengungkapan CSR terhadap kinerjakeuangan yang diproksikan oleh ROA pada perusahaan sektor keuangan (financials) pada Bursa Efek Indonesia (BEI) selama pandemi Covid-19 tahun 2020 menunjukkan bahwa CSR terhadap kinerja keuangan yang diproksikan oleh ROA memiliki nilai signifikan sebesar 0,162 > 0,005, sehingga dapat dijabarkan bahwa Pengungkapan CorporateSocialResponsibility tidak berpengaruh secara signifikan terhadap KinerjaKeuangan yang diproksikan dengan ROA atau Ha ditolak. Lalu, besar pengaruh antara variabel CSR dengan kinerjakeuangan (diproksikan oleh ROA) sebesar 3,3\% yang mengartikan bahwa garis regresi memiliki ketepatan yang buruk.

Tidak berpengaruhnya Pengungkapan CSR terhadap Kinerja Keuangan Perusahaan selama pandemi Covid-19 mungkin disebabkan karena pandemi ini cukup mengguncang pendapatan sebagian masyarakat yang disebabkan karena adanya kebijakan PSBB yang menuntut masyarakat untuk mengurangi aktivitasnya diluar ruangan dan menyebabkan aktivitas beberapa sektor usaha sedikit terganggu, tidak terkecuali sektor perdagangan. Hal tersebut cukup merugikan perusahaan sektor keuangan dikarenakan sektor perdagangan merupakan penyumbang sebagian besar permintaan kredit. Selain itu, penutupan beberapa sektor usaha menyebabkan turunnya sebagian besar pendapatan masyarakat khususnya pengusaha mikro dan pekerja informal pendapatan harian yang berdampak pada penurunan daya beli masyarakat. Hal tersebut karena masyarakat memilih untuk menunda belanja dan melakukan saving keuangan, padahal pertumbuhan kredit perbankan sangat dipengaruhi oleh konsumsi rumah tangga dan daya beli masyarakat. Hal inilah yang berimbas pada pembengkakan kredit macet hingga banyaknya permintaan restrukturisasi dan relaksasi kredit yang mengakibatkan turunnya kinerja keuangan perusahaan sektor keuangan selama pandemi Covid-19.

Namun, kondisi pandemi yang cukup mengguncang daya beli sebagian masyarakat ini yang akhirnya pengungkapan CSR yang dilakukan perusahaan tidak terdapat respon yang baik dari masyarakat. Aktivitas CSR tidak berpengaruh pada naiknya laba atau kinerja keuangan perusahaan karena pengungkapan CSR tidak serta merta membuat masyarakat meningkatkan daya belinya dan melakukan permintaan kredit. Upaya yang dilakukan perusahaan dengan menurunkan suku bunga kreditpun tidak cukup untuk meningkatkan pertumbuhan kredit pada masa pandemi ini. Hal ini karena daya beli masyarakat dipengaruhi oleh faktor eksternal seperti penurunan pendapatan masyarakat, bukan oleh faktor internal perusahaan. Maka dari itu, cukup sulit bagi sektor keuangan untuk memperoleh dan meningkatkan laba usahanya di masa pandemi ini.

Sulitnya meningkatkan laba yang berimbas pada rendahnya tingkat ROA selama pandemi Covid-19 ini yang mungkin mengakibatkan tidak berpengaruhnya CSR terhadap kinerja keuangan. Pada awalnya, pengungkapan CSR diharapkan dapat meningkatkan citra atau reputasi perusahaan dan akan menerima kepercayaan dari masyarakat yang mana hal ini akan membuat masyarakat tertarik untuk menggunakan produk dan jasa seperti pengajuan kredit, menabung, menggunakan jasa asuransi dan lain sebagainya. Selain itu, pengungkapan CSR yang dilakukan perusahaan juga diharapkan dapat menarik simpati para pemegang saham untuk 
berinvestasi. Hal inilah yang membuat pengungkapan CSR dipercaya dapat membawa keuntungan dan dapat meningkatkan kinerja keuangan perusahaan. Namun pada kondisi pandemi seperti ini dimana untuk bertahanpun sulit, bahkan banyak perusahaan yang yang harus menghentikan operasinya secara permanen di masa pandemic ini, sehingga meningkatkan kinerja keuangan tidak hanya sekedar menerapkan CSR saja namun membutuhkan banyak faktor lain yang tidak dijelaskan dalam penelitian ini.

Hasil penelitian ini sejalan dengan penelitian yang dilakukan oleh Bae, dkk (2021) bahwa mereka tidak menemukan adanya bukti mengenai hubungan CSR dengan kinerja keuangan selama krisis Covid-19 (19). Pendapat lain diungkapkan dalam penelitian Yadav, dkk (2021) bahwa mereka menemukan hubungan berbentuk U (U-Shaped) antara aktivitas CSR dengan kinerja keuangan selama pandemi Covid-19 (20).

\section{Kesimpulan}

Bersumber pada penjelasan yang telah dipaparkan, di tarik kesimpulan sebagai berikut:

1. Pengungkapan Corporate Social Responsibility pada perusahaan sektor keuangan yang terdaftar di Bursa Efek Indonesia (BEI) di masa pandemi bahwa seluruh perusahaan telah melakukan pengungkapan CSR pada kategori ekonomi, namun pada kategori sosial dan kategori lingkungan masih terdapat beberapa perusahaan yang tidak menerapkan setiap item-item yang ada dalam standar GRIG4.

2. Kinerjakeuangan (diproksikan dengan ROA) pada perusahaan sektorkeuangan yang terdaftar di Bursa Efek Indonesia (BEI) di masa pandemi rata-rata lebih rendah daripada standar industri rasio profitabilitas untuk Return on Asset.

3. Pengungkapan Corporate Social Responsibility (CSR) tidak berpengaruh terhadap Kinerja Keuangan yang diproksikan dengan Return on Assets (ROA) pada perusahaan sektor keuangan yang terdaftar di Bursa Efek Indonesia (BEI) selama pandemi Covid19 tahun 2020.

\section{Acknowledge}

Dalam penyusunan artikel ini, penulis sangat berterima kasih kepada pihak-pihak yang membantu, khususnya kepada Ibu Yuni Rosdiana, S.E., M.Si., Ak., CA. selaku dosen pembimbing.

\section{Daftar Pustaka}

[1] Handini S. BUKU AJAR: MANAJEMEN KEUANGAN. Handini S, editor. Surabaya: Scopindo Media Pustaka; 2020.

[2] Adisetiawan R. Analisis Pengaruh Kinerja Keuangan dalam Memprediksi Pertumbuhan Laba. J Apl Manajemennajemen. 2012;10(3):669-81.

[3] Satria. MAJ, Sunaryo. H, ABS. MK. e-jurnal Riset Manajemen PRODI MANAJEMEN Fakultas Ekonomi Unisma Website : e-jurnal Ris Manaj Prodi Manaj. 2017;51-69.

[4] Hery. Analisis Kinerja Manajemen: Menilai Kinerja Manajemen Berdasarkan Rasio Keuangan. Jakarta: Grasindo; 2015. 25 p.

[5] Febryan, Rezkisari I. Cerita Dampak Corona di Masyarakat Ekonomi Kelas Bawah [Internet]. 2020. Available from: https://republika.co.id/berita/q8vbf9328/cerita-dampakcorona-di-masyarakat-ekonomi-kelas-bawah

[6] Setiawan SRD. Survei: 84 Persen Masyarakat Akui Pendapatan Turun karena Corona [Internet]. $2020 . \quad$ Available from: https://money.kompas.com/read/2020/06/26/122922726/survei-84-persen-masyarakat-akuipendapatan-turun-karena-corona?page=all\#: :text=Pandemi Covid-19 berdampak langsung,persen dibanding sebelum pandemi ini.

[7] Akbar UR, Humaedi S. Peran CSR dalam Upaya Mengatasi Pandemi COVID-19. 2020;

[8] Wati LN. Model Corporate Social Responsibility (CSR). Ponorogo: Myria Publisher; 2019. $1 \mathrm{p}$. 
[9] Meutia I. Menata Pengungkapan CSR pada Bank Islam (Pendekatan Teori Kritis). Yogyakarta: Deepublish (Grup Penerbitan CV Budi Utama); 2021. 8 p.

[10] Syairozi MI. Pengungkapan CSR pada Perusahaan Manufaktur dan Perbankan. Tidar Media; 2019. $59 \mathrm{p}$.

[11] Mattila M. Corporate social responsibility and image in organizations: For the insiders or the outsiders? Soc Responsib J. 2009;5(4):540-9.

[12] Bowen HR. Social Responsibilities of the Businessman. Amerika Serikat: University of Lowa Press; 2013.

[13] Visser W, Matten D, Pohl M, Tolhurst N. The A-Z of Corporate Social Responsibility. 2010. $504 \mathrm{p}$

[14] Global Sustainability Standards Board. Pedoman Pelaporan Keberlanjutan G4. Glob Report Initiat. 2013;1-97.

[15] Mowen MM, Hansen DR, Heitger DL. Dasar-Dasar Akuntansi Manajerial Edisi 5. Jakarta: Salemba Empat; 2017.

[16] Jewell JJ, Mankin JA. What Is Your Roa? an Investigation of the Many Formulas for Calculating Return on Assets. Acad Educ Leadersh J. 2011;15(Special Issue):79-91.

[17] Sofianty D, Lestari R. SPSS. Bandung: Laboratorium Akuntansi Fakultas Ekonomi dan Bisnis UNISBA; 2020.

[18] Lukviarman N. Dasar Dasar Manajemen Keuangan. Padang: Andalas University Press; 2006.

[19] Bae KH, El Ghoul S, Gong Z (Jason), Guedhami O. Does CSR matter in times of crisis? Evidence from the COVID-19 pandemic. J Corp Financ. 2021;67(December 2020):101876.

[20] Yadav, Sandeep, Srivastava, Jagriti. CSR , audit quality and firm performance during COVID-19: an organizational legitimacy perspective. Indian Inst Manag Kozhikode. 2021;(108967). 